\title{
Developing Interactive Learning Multimedia of Automatic Transmission in Motor Vehicles
}

\author{
Tawardjono, Bambang Sulistyo, Yosep Efendi \\ Department of Automotive Engineering Education, Faculty of Engineering, Universitas Negeri Yogyakarta \\ Yogyakarta, Indonesia \\ Email: tawardjono@uny.ac.id
}

\begin{abstract}
This research aims to develop learning media of automatic transmission based on flash. The procedure of developing the media starts from identifying the problem, collecting information, understanding the product design, validating the design, and testing the product. The result of this research is learning media of automatic transmission based on flash with percentage of appropriateness: (1) assessment from material experts as many as $77.33 \%$ with appropriate category, and assessment from media experts as many as $\mathbf{7 6 . 8 \%}$ of appropriate category, while assessment form students shows $\mathbf{8 3 . 2 6 \%}$ appropriateness when it is seen from the material aspect, and $82.28 \%$ when the assessment is seen from the aspect of media with very appropriate category; (2) the difference of mean from learning is $16.67 \%$ from a class which uses media. Hence according to the results, the learning media of automatic transmission with flash-based are proper to be used in the teaching-learning process, and they are effective because they are able to develop students' study results for students who use the media.
\end{abstract}

Keywords: learning media, automatic transmission, interactive animated media

\section{INTRODUCTION}

One of the national purposes is to educate Indonesians. This achievement of the national aim is done through education. Education involves learning activities or learning processes. Starting from primary education to higher education, teachinglearning processes and facilities are things to consider because the learning processes are an essential component in interactive education. Similarly, facilities as supporting media are also important to implement the learning processes.

In a teaching-learning process, there are two crucial things: method and learning media. The two aspects are interrelated. The learning method is a way to explain a learning material. In explaining the material, an educator usually employs media or facilities. Learning media are facilities of communication to send a message from the message source for a recipient to support the learning process. Educational media make the teaching-learning process more interesting for students and the material delivery in learning will be clearer. Thus, students can understand the material more and the aim of learning can be achieved.

Characteristics of good media are interesting and understandable. Interesting can be meant that the media can optimize the students' attention in following a learning activity.
Moreover, understandable can be meant that the media explain a material clearly and orderly. Therefore, students will not be confused in understanding a material which is being conveyed.

Educational media will also make a learning material more varied, not only from educator's verbal communication but more than that. Thus, students will not be bored and educators can teach students efficiently and effectively. Besides, through media, students will do more learning activities because they will not only listen to the educator's explanation, but they will also do other activities such as observing, doing and demonstrating. A kind of learning media which can be used as learning media is computer-based media. Computer-based media has many advantages such as displaying a moving picture or animation. The use of computer-based media as learning media will make a more interesting learning situation, compared with the listening method of learning. In a learning process, it is required to make students happy. The reason is that when students are joyful in learning, the students' interest in learning a subject will increase. As a consequence, the interest will grow a positive attitude and affects students' ability in understanding the subject. Therefore, students are expected to understand the material which is being conveyed easier.

A fact shows that computer-based media, which can display a moving picture or animation, have not been used by many educators. On the other hand, the media can help the teachinglearning process to be more effective and efficient. To cope with the problem in the conventional teaching, an engineering technology by designing learning media is needed; however, the media are ones which have functions and advantages more than conventional learning. Therefore, the material which is being conveyed is easier to be understood by students, even for a material with a high level of difficulty. Considering the benefits of the computer-based media, it is necessary to develop the media. The teaching-learning media are not only for primary education, but they are also for all levels of education, including higher education.

A university which focuses on observing and developing teaching and all things related to teachers is Yogyakarta State University (UNY). The university with an Educational Institution of Educational Staffs (LPTK) base is consistent in developing various models, methods, and learning media which are in accordance with the needs of various departments in UNY. A department in UNY which always employs learning media is Automotive Engineering Education in Faculty of 
Engineering. As one of the vocational departments, a training object and learning media are important parts of teaching process in Automotive Engineering Education, especially for a course with a high difficulty level.

One of the courses requiring media in every teaching is Power Train System course with course code OTO6321. This course is obliquely taken by all students from Department of Automotive Engineering Education whether for Diploma's or Bachelor's degree in the first semester of the second year. Teaching materials within the course are mostly advanced materials from basic materials which are already learned in the previous semesters. Although so, most students consider that materials in Power Train System course have a high level of difficulty, proven by some students who have not passed the course. A material in Power Train System course having a high level of difficulty is Automatic Transmission System in cars. The automatic transmission material contains a working cycle and fluid current which cannot be directly observed. As a result, educators need learning media which can help students in understanding the material. Until this time, teaching-learning process in Power Train System course with the automatic transmission subfield is done with limited training objects and teaching materials, even though to master the material, training objects and teaching materials are needed to assist students in understanding the material. In other words, the learning media containing a teaching material are still restricted because educators only use textbooks. Therefore, the conventional teaching system needs to be changed with media-based teaching.

According to the advantages of computer-based media explained in the previous paragraphs, computer-based media, which are animated media, are crucial to develop learning media for Automatic Transmission System because characteristics of Automatic Transmission System are relevant with the concept of animated media, especially for explaining the working system of Automatic Transmission System. Therefore, developing animated media is significant for Automatic Transmission System in this research.

\section{A. Learning Media}

The word media derived from Latin medius which means center or medium. According to Association of Education and Communication Technology (AECT 1977), media is a form and a channel is used to express a message or information. In addition to the delivery system, media which are often changed into mediator according to Fleming in Azhar Arsyad, 2010:3) is a cause or a tool which intervenes two parties and reconciles them. Hamalik (1986) in Azhar Arsyad (2010:15) states that the use of learning media in a teaching-learning process can raise desire and a new interest, motivate students in a learning activity, and even give a psychological influence for students. The use of learning media in the learning orientation level will assist the effectivity of learning process and message delivery in a course.

From some definitions of media, a conclusion which can be drawn is that learning media are beneficial as a mediator which can be used to deliver information and a material. Besides, media can also develop students' understanding, motivation, and interest.

\section{B. Visual Design Process}

According to Heinich (1996), the first step in designing a visual display is by making and collecting illustrations in the form of pictures and design of text which will be used. Things to be considered are Visual Element, Verbal Element, Element that Add Appeal, Alignment, Shape, Balance, Style, Color Scheme, Color Appeal, Proximity, Directionals, Figure-Ground Contrast, and Consistency.

\section{1) Visual element}

There are three visual symbols. (a) Realistic visual describes an object actually or in accordance with the reality. An object or an actual phenomenon will always have an aspect which cannot be illustrated, even in a three dimension picture. (b) Analogic visuals illustrate a concept or a topic by using another object which has a similarity; (c) Organizational visuals consist of a diagram, a map, or a scheme. This graphical picture shows a relation between main points or concepts in a material.

\section{2) Verbal Element}

A letter is the smallest part of a word. Letter Style, a type of word which can be chosen should be consistent and harmonic with other elements in a visual design. For the need of learning message design, a simple letter type is preferred. A number of Lettering Style, A visual display or visual display series should not use more than two letters and the two letters must be in accordance with each other. A capital letter is better to be used only in a particular time, i.e. abbreviation, initial letter/name. In contrast, the color of words/letters should be contrasted with the color of the background. For size lettering, the body text is between $9 \mathrm{pt}$ to $14 \mathrm{pt}$, whereas a headline/title can be more than 14pt. Another important aspect is Spacing between Letters. It should not be too wide. However, Spacing between Lines is necessary for legibility. When the spacing is too close, the text will be illegible. On the other hand, when the spacing between lines is too far, the text in a display will seem less united.

\section{3) Elements That Add Appeal}

A visual display will be meaningful when it can attract viewers' attention. A fundamental thing which can draw attention from someone is because the existence of something which is unpredicted. The unpredicted thing can be in the form of an extraordinary metaphor usage and strong iridescence. Most visual displays are in two dimensions; however, a designer can also create the display into three dimensions by using texture and actual materials. The texture is a character of three-dimensional object or material. Besides, an interaction is also important to give a response towards a visual display by manipulating material existing in the display.

\section{4) Alignment}

The letter is the smallest part of a word. Letter style which is chosen should be consistent and harmonic with other elements in a visual design. For the need of learning message design, a simpler letter style has a reading level which is good for a long text. (b) Right text alignment is bad and not 
recommended for a long text. (c) Right, and left text alignment is good enough, mainly when a space between words is wellcontrolled. The alignment is recommended for a long text because it seems tidy. (d) Center text alignment is not recommended for a long text because it seems static.

\section{5) Shape}

To make a visual element and verbal element is by choosing and putting them in a familiar form, i.e. geometrical forms because the forms are easy for viewers to guess. Another principle which can be used as a guide for placing a visual element is that visual element is put in one-third from a top-left corner.

\section{6) Balance}

Size weight and position of text in a display design should be controlled in balanced. The elements which are placed in a good order are good to be seen. How to test balance can be done by seeing the left and right part. Fundamentally, there are two kinds of balance: formal and informal. Formal balance is a design which is formally balanced and having the same size and form elements in the left and right part. In informal balance, an object is placed randomly on a page. The form of the design needs a simple concept, but the effect can be imaginative and dynamic.

\section{7) Style}

The style is determined by different conditions in a field. A display design which is for children's learning will have a different display design with adults' learning.

\section{8) Colour Scheme}

Color is a crucial visual element and an interesting sight. Color can play a role in giving a realistic image. Besides, it can also function as dividing visual elements, drawing attention, strengthening mood of a message, and giving an artistic display.

\section{9) Colour Appeal}

The choice of color is significant for keeping the display, readers' or users' interest. Blue, green, and purple are considered as cool colors, whereas red and orange belong to warm colors. When choosing a color, a designer needs to see the emotional situation of what is wanted to be achieved through a display.

\section{0) Proximity}

Proximity element is an element grouping. Interconnected elements are placed adjacent, whereas elements which are not interconnected should be disassociated. Thus, viewers can be easier to catch the meaning of a display.

\section{1) Directional}

Viewers see a display by directing their sights to every part of a display alternately. A designer can set viewers' attention by giving a direction in a display, and it is what is called as directional. There are some ways which can be used to attract viewers' attention. One of some ways is by using an arrow.

\section{2) Figure-Ground Contrast}

Figure-ground contrast is a way to create an element or a group of elements which stand out through some ways: text contrast, direction contrast, size contrast, and form contrast. A simple principle for figure-ground contrast is that a bight figure is suitable with a dark background and vice versa.

\section{3) Consistency}

In a process of making a visual display order, consistency is a fundamental principle which cannot be neglected. Therefore, the viewers will not get confused.

\section{Automatic Transmission System Competence}

Automatic transmission system competence which is taught is having the aim to give the students know about the automatic transmission fundamentals. The material used in the automatic transmission learning media is Flash-based. Here, in support the automatic transmission learning application, it must suit the Semester Learning Plan on Transfer Energy System subject in Automatic Transmission competence in the syllabus which is used in Vocational High School or SMK.

Based on the various sources of literature, basic competence and the main topic of Automatic Transmission competence that will be discussed in the Flash-based automatic transmission learning application are as follows:

TABle 1. BASIC COMPETENCE AND MAIn COMPETENCE.

Basic Competence
1. The students are able to know, understand, and analyze the
automatic transmission unit on planetary type.
The students are able to:
1. know Competence
2. explain the main components and the functions of automatic
transmission
understand gear planetary unit procedure in the automatic
transmission unit

According to some considerations which have been investigated about the material, it is said that the material which will be presented in the Flash-based automatic transmission learning application refers to the basic competence which is appropriately suited with the syllabus.

\section{METHOD}

The type of the research is Research and Development ( $\mathrm{R}$ $\& \mathrm{D})$. The method of Research and Development is a research method that is used to result in a certain product and test the effectiveness of the product (Sugiyono, 2008). Development Model is a base to develop the product that will be resulted. The model can be in the form of the procedural, conceptual, and theoretical model.

The steps of the development of computer-based automatic transmission learning application on Transfer Energy System subject in Automotive Engineering Education Department FT UNY can be clearly seen in the following flowchart. 


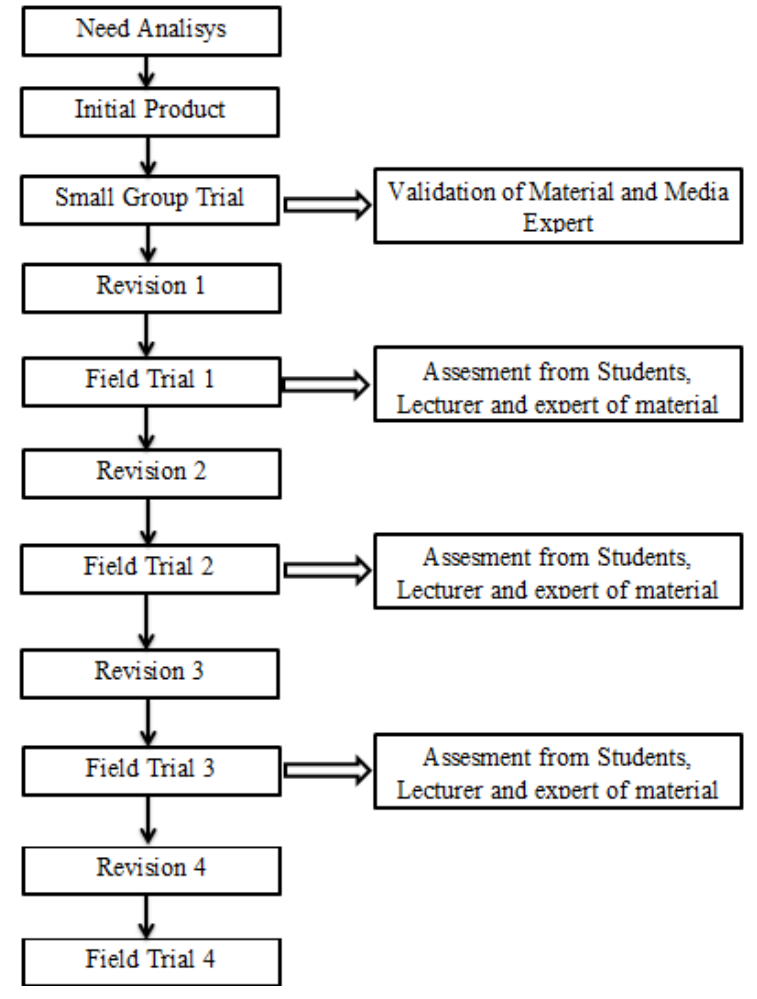

Fig. 1. The Steps of the Media Development Research.

\section{A. Product Trial}

The product trial of the developmental product was done in three steps including a) The small group trial which aimed to test the product to the students of Automotive Engineering Education Department FT UNY and Vocational high school students, as well as validation test done by media and material expert. The trial was aimed to get the product assessment before widely used. b) The field trial involved numbers of students of Transfer Energy System class and vocational high school students; c) The last field trial involved the students of Transfer Energy System class. Those were done for getting the data about the students' interest in the learning media.

\section{B. Research Subject}

In conducting the research, subjects who were chosen for doing the product validity test are the material experts who were chosen from two lecturers of Automotive Engineering Education Study Program UNY and two lecturers as media experts who are also from Automotive Engineering Education Study Program UNY. The research subject for small group trial was the students of Transfer Energy System class, Automotive Engineering Education Department FT UNY and students of the vocational high school. The field trial respondent was the students of Transfer Energy System class, Automotive Engineering Education Department FT UNY.

\section{The Technique of Data Collection and Analysis}

In this research, the researchers used questionnaire, testquestion, and observation in collecting the data. The instrument that was used by the media experts was in the form of a questionnaire or close questionnaire. The close questionnaire is a questionnaire where the respondent must choose one of the alternative statements that are available. Media experts' questionnaire loaded some aspects which are suitable for the learning media including interpretation, visual design, graphics as visual, and also the media development aspect. Data analysis technique employed in the research is descriptive-analysis technique. The researchers used a Likert scale to categorize the feasibility of the learning video.

\section{RESULT AND DISCUSSION}

\section{A. Flash-based Automatic Transmission Learning Media Product Development}

Flash-based learning media for automatic transmission material has been tested in needs analysis, the development based on the needed, trial and revision according to the experts' and respondents' suggestion. The needs analysis really helped the researchers to make the media that is suitable with the students' need. This is really important because the students are users who have roles as the main characters in teachinglearning processes; here teachers and lecturers only act as facilitators. For that reason, the processes of accumulating and accommodating students are the important processes that should be passed to develop this learning media. After the teachers/lecturers knew the students' need for the interesting learning media, then the media storyboard was starting to be arranged. The storyboard was developed and applied in making the set of the equipment of the media which is consisted of the picture, video, and text. Those three aspects are considered as an attractive thing by the respondents, with the result that it can improve the students' interest in learning the material, mainly in the automatic transmission material.

With the assumption that the students are interested to learn about the automatic transmission with the animation media, then it will affect their study result. Even though the result of the study will be different, at least their study interest will increase because of the animation media. Another thing that is quite important in the learning aspect is the increase of the study motivation and the students who are more being active because of learning with animation media. Through the animation media, the students will be more active, because the media is developed by using Flash-based which is interactive. The media also can be used everywhen and everywhere with the computer device or even laptop. Thereby, students' access and learning activity become wider and flexible. It will affect their process and their result of the study in a positive way. The media does not only focus on the teaching material. It also contains the evaluation element. Evaluation is really important for the users, so they can measure their ability and understanding of the material that is shown in the media. By giving the evaluation menu in the media, the students can measure their ability and understanding by themselves. If they got the unsatisfying evaluation, they can repeat to study it as 
well as do the evaluation again. With all of the facilities, the media is believed can give the students positive effects in learning processes, mainly in the automatic transmission competence.

\section{B. Flash-based Automatic Transmission Learning Media Product Feasibility}

The feasibility of a media must be measured in order to know the role and the characteristics of the media that is developed. Basically, the feasibility test is done to confirm whether the development media aspect is actually suitable with the need that is proposed by the research respondent or not. The feasibility test consists of two aspects including; material and media aspects. The result of the research proved that Flashbased automatic transmission learning media was seen in the material aspect, it achieved the proper assessment from the material experts with $77,33 \%$. The result marked that the material that is used in the media was already suitable with the competence in the syllabus or RPS, both in the Automotive Engineering Education Department FT UNY mainly in the Transfer Energy System subject (Automatic Transmission competence) and in the vocational high school syllabus in the Automatic Transmission subject,

Besides the material, another important thing from the material aspect is a material arrangement which is presented in the flash media. Ascertainable, the material experts assessed the material was feasible and in order. It made light of the users to understand the material that is shown in the media. After getting the feasible assessment from the material experts, the researchers arranged the material that will be shown in the media. Besides the feasibility test done by the material experts, the media also tested by the respondents (vocational high school students and college students). The feasibility test by the respondents has resulted in a really feasible category with the average percentage of $83,26 \%$. Material aspect is including the material compatibility, material presentation technique, as well as supporting material. Based on the data analysis and product trial, it showed that the Flash-based automatic transmission learning media is feasible to be used in the learning process.

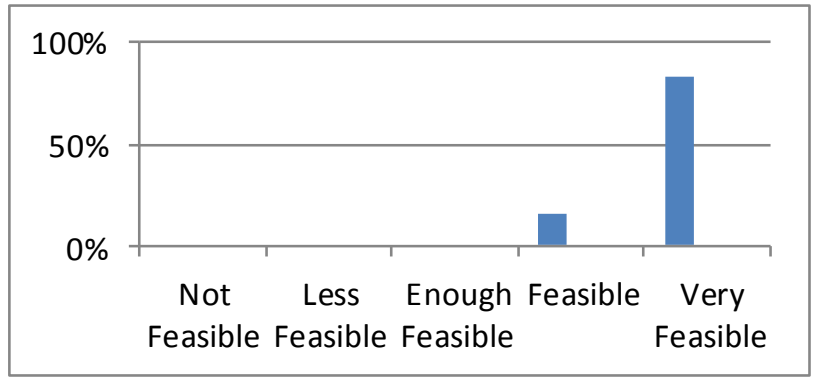

Fig. 2. The feasibility test by the Material Aspect

The second aspect test is media display aspect. From the media display aspect, the result of the feasibility test proved that the automatic transmission learning media product was stated feasible with the average percentage of $76,8 \%$. Meanwhile, in the product trial, the media came out as a very feasible category. With the feasibility, percentage reached $82,28 \%$.

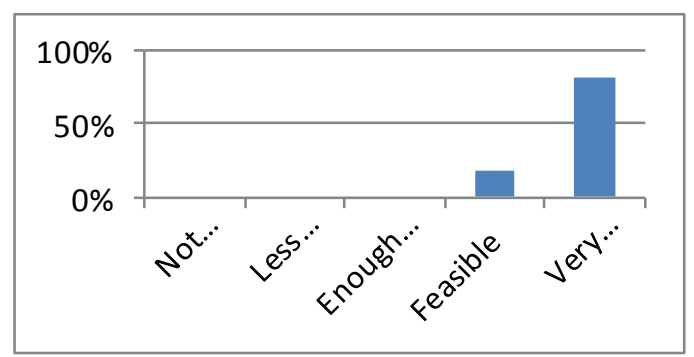

Fig. 3. The feasibility test by the Media Aspect

Media aspect consists of the compatibility of the learning media design product as seen from the visual media, as well as the media design product which is developed. Based on the data analysis and product trial, it showed that the learning media is feasible to be used in the learning process. According to the material and media aspect, it showed that Flash-based automatic transmission learning media product is really useful and also attract the students as well. In short, both the material and display aspect of the learning media is feasible to be used in the learning process.

\section{The Effectiveness of the Use of Flash-based Automatic Transmission Learning Media Product towards the Increase of the Students' Learning Outcome}

To know the effectiveness of the automatic transmission learning media is by applying the media in the teachinglearning process, either in the in the Automotive Engineering Education Department FT UNY or in SMK N 1 Magelang. The result of the research proved that the students are really enthusiastic during they followed the teaching-learning process about the automatic transmission. The students commented the teaching-learning process become more interesting and it makes them increasing their study interest. It signs that the learning media is effective in increasing motivation and study interest.

Besides, the learning media also improve respondents' study outcome. The thing is known when the media is used in SMK Negeri 1 Magelang which is done by the college students who also the members of the research. The application result in SMK showed that the automatic transmission achieved the average value 78,62 . Meanwhile, the learning process without media only reached the average value 62,10 . With those results, it can be concluded that this learning media is having a good impact towards students' grade.

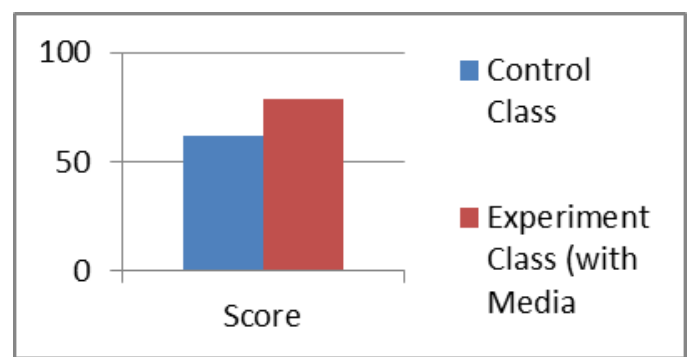

Fig. 4. The Effectiveness of the Use of Flash-based Automatic Transmission Learning Media 
The good result is caused by the media is because the students are easier to understand the material. The automatic transmission learning media which is interactive and having clear video contents can help the student to more understand the material. By understanding the material that is presented, it will affect their study outcome.

\section{The Final Display Media Research and Development Result}

After the interface design step and procedural design as well as all of the revisions. These are the visual appearance of some media that is already developed

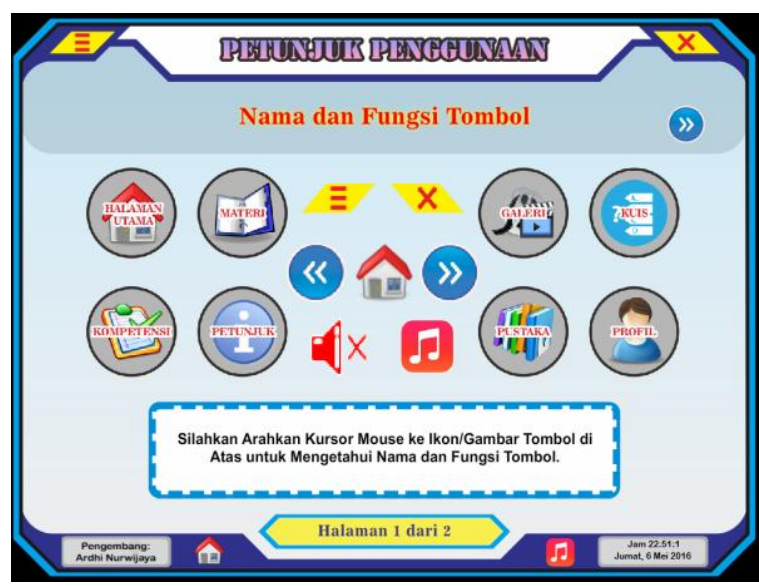

Fig. 5.User Page Views

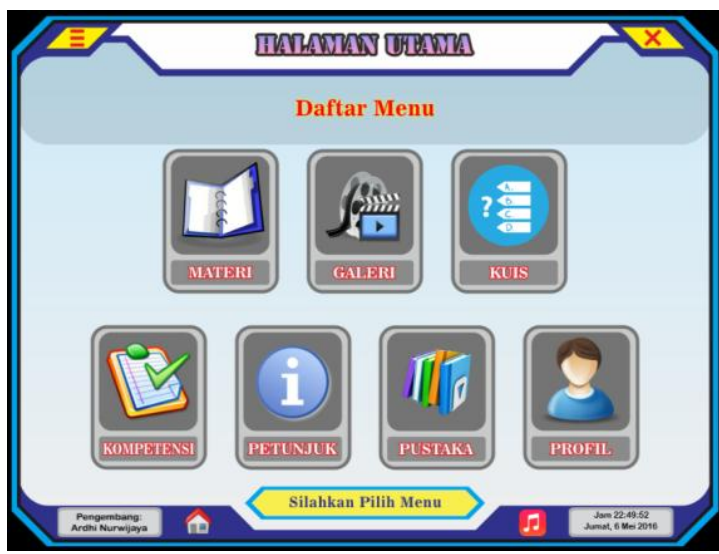

Fig. 6. The Main Menu Display

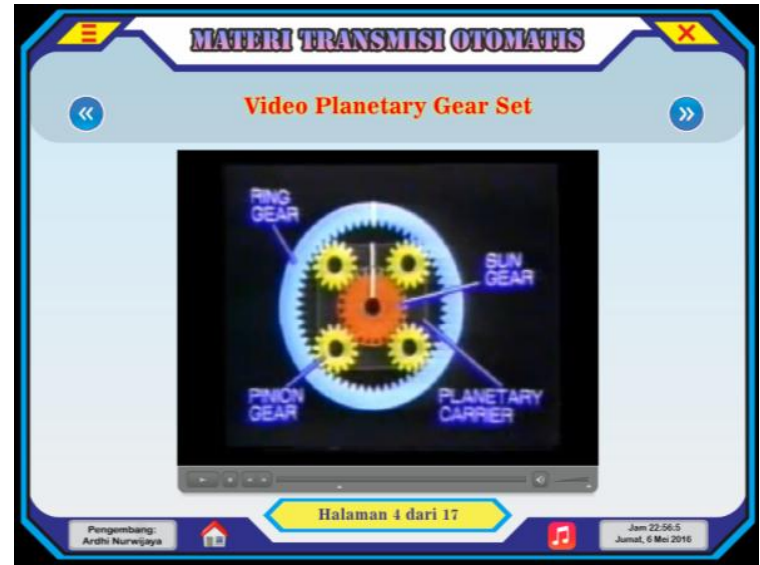

Fig. 7. Video Material Display Page

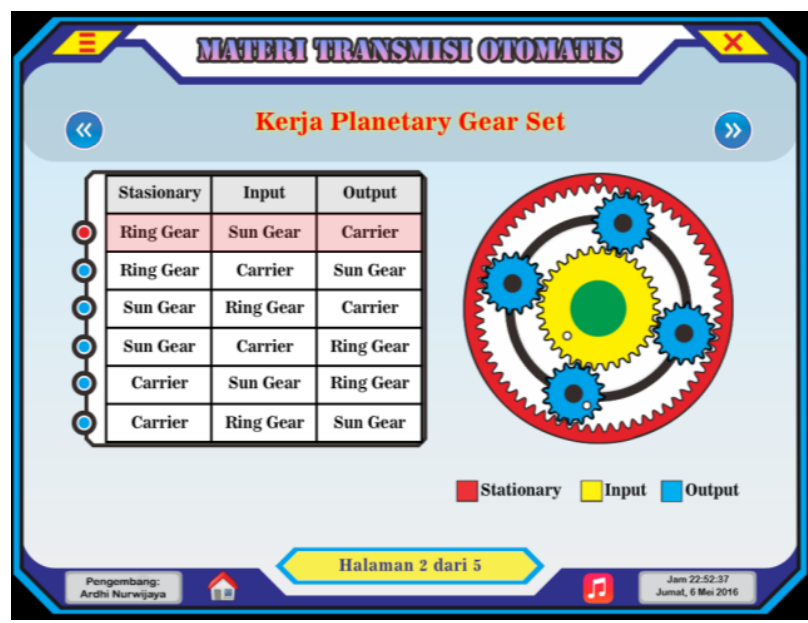

Fig. 8. Animation Material Display Page

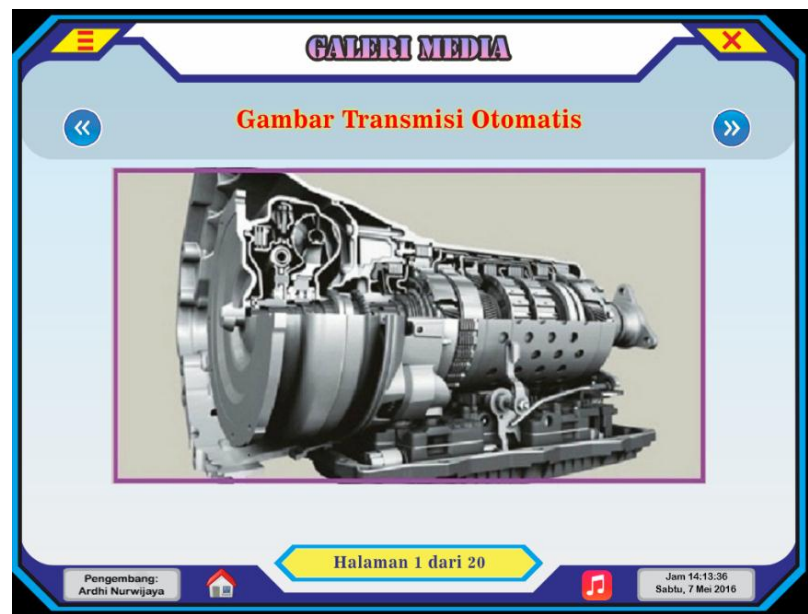

Fig. 9. Picture Gallery Display Page (Transmission Picture by Novriza, 2012) 


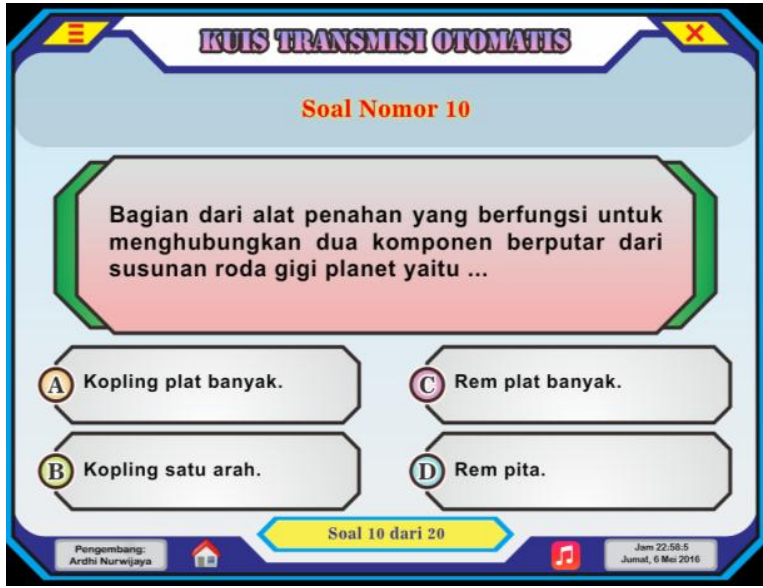

Fig. 10. Quiz Display Page

\section{CONCLUSION}

According to the result of the research, the researchers could draw some conclusions as follows:

1. The Automatic Transmission Learning Media in the Automotive Engineering Education Department FT UNY is still limited and conventional. So it still needs the learning media which is more attractive, effective, and efficient, that is flash-based learning media.

2. The development of flash-based Automatic Transmission Learning Media process consists of some steps including identification of the problem, the information collection, product design, design validation, and product trial.

3. Learning media product is made by the Adobe Flash Professional program with the support of the other programs such as Adobe Photoshop, Camtasia Studio, Corel Draw, Flash Decompiler, and Format Factory.

4. The Automatic Transmission learning media is already suitable with the students' need. The thing is done by collecting and analyzing the things that are needed in the learning process from the respondents.

5. Based on the product design validation by media experts and material experts, the automatic transmission learning media development is feasible with the percentage of feasibility $77,33 \%$ as seen from material aspect, and 76,85 seen from the media aspect. Meanwhile, according to the main product trial, the automatic transmission learning media is feasible to be used as learning media. As seen from the material aspect, it shows the feasible criterion $83,26 \%$ and if it is seen from the media aspect, it showed the feasibility criterion $82,28 \%$.

6. The result of research about the product effectiveness shows that the product is effective to be used in the learning process because it can increase the students' study outcome. It is shown by the grade that is higher when the students are learning with the media rather than using the conventional method.

\section{REFERENCES}

[1] Azhar, Arsyad. (2002). Media Pembelajaran. Jakarta: PT Raja Grafido Persada.

[2] Heinrich, R. et, al. (1996). Instructional Media and Technologies for Learning (5th Edition). New Jersey: Englewood Cliffs.

[3] Novriza. (2012). Modul Memperbaiki Transmisi. Medan: Creatacom.

[4] Sugiyono. (2007) (2011). Metode Penelitian Kuantitatif Kualitatif dan R\&D. Bandung: Alfabeta 